Article

\title{
Construction and Demolition Waste in Romania: The Route from Illegal Dumping to Building Materials
}

\section{Florin-Constantin Mihai}

Department of Research, Faculty of Geography and Geology, Alexandru Ioan Cuza University, Carol I Blvd., Nr. 20A, RO-700505 Iasi, Romania; mihai.florinconstantin@gmail.com

Received: 29 March 2019; Accepted: 2 June 2019; Published: 6 June 2019

\begin{abstract}
The paper performs a critical overview concerning the construction and demolition waste (C\&DW) management issues in Romania. Five main stages related to C\&DW management are highlighted such as: (i) illegal dumping on public lands; (ii) C\&DW collection and disposal in urban landfills; (iii) C\&DW treatment and reuse in civil constructions (roads, coating material for landfills); (iv) regional integrated waste management systems; (v) recycling of building materials (e.g., cement industry and recycled aggregates). The paper reveals the poor monitoring of C\&DW flows across Romanian counties and the geographical dimension of this waste stream collected by waste operators. The paper examines the current challenges in Romania and it reveals the future prospects to provide a reliable transition towards sustainable C\&DW management activities. The targeted route: waste fractions can be recycled and/or reused as building materials via integrated waste management systems, which enable a circular economy in urban and rural municipalities.
\end{abstract}

Keywords: construction and demolition waste (C\&DW); waste management; recycling; recovery; sustainability; circular economy; illegal dumping

\section{Introduction}

Construction and demolition wastes $(\mathrm{C} \& \mathrm{DW})$ are one of the fastest-growing waste streams due to the economic development and urbanization process at a global scale. Construction waste presents a huge amount of building materials which could be reused, recycled, or recovered avoiding natural resource depletion in terms of raw materials for the construction sector [1]. This great recovery and recycling potential is lost via the lack of waste collection facilities (wild dumps) or poor recycling schemes (landfill based systems). Illegal dumping and landfills are the main disposal options across the world, causing environmental pollution, deterioration of the landscape, and consumption of landfill capacity. Mixing of C\&DW with municipal solid waste (MSW) is a real issue because of the non-existence of effective systems and rules for segregation of C\&DW in many countries [2]. Around one third (i.e., 1 billion $\mathrm{t}$ ) of total $\mathrm{EU}$ wastes come from construction and demolition activities where France, Germany, and the UK are the main contributors [3].

However, various waste definitions and reporting systems across the EU impose cautions in geographical comparison of C\&DW flows. C\&DW is mainly generated due to design errors, improper procurement, and planning, inefficient material handling, residues of raw materials and unexpected changes in building design [4]. There are many stakeholders (e.g., customers, subcontractors, suppliers, waste operators, municipalities, etc.) involved in the construction sector with complex responsibilities, which lead to various decision-making chains across EU Members [5]. The poor availability of land in growing urban areas for landfill sites or peculiar geographical areas (e.g., Islands) impose new alternative for C\&DW flows. Romania is still a landfill-based country where recycling and 
recovery activities must be further developed in order to comply with the EU regulations on the waste management sector. This paper aims to examine the C\&DW activities in Romania starting from the worse case option (illegal dumping) towards sustainable pathways targeting this fraction as a building material in the construction sector under a circular system. The paper reveals the challenges, which other transition and developing countries across the world could face in providing a sound waste management system for this waste stream.

\section{Materials and Methods}

Based on the literature review, environmental reports, and field observations; the paper identifies main five development stages from the worst-case scenario (stage I) where C\&DW is illegally dumped on surroundings without any treatment towards new building materials using recycled fractions as a best-case scenario as shown in Figure 1. Rural communities and smaller urban areas are still facing illegal dumping issues due to the lack of proper waste management facilities as pointed out in Section 3.1. This undesirable situation is specifically for stage I, where public lands, roadsides, water bodies, and forest areas are frequently exposed to such bad practices.

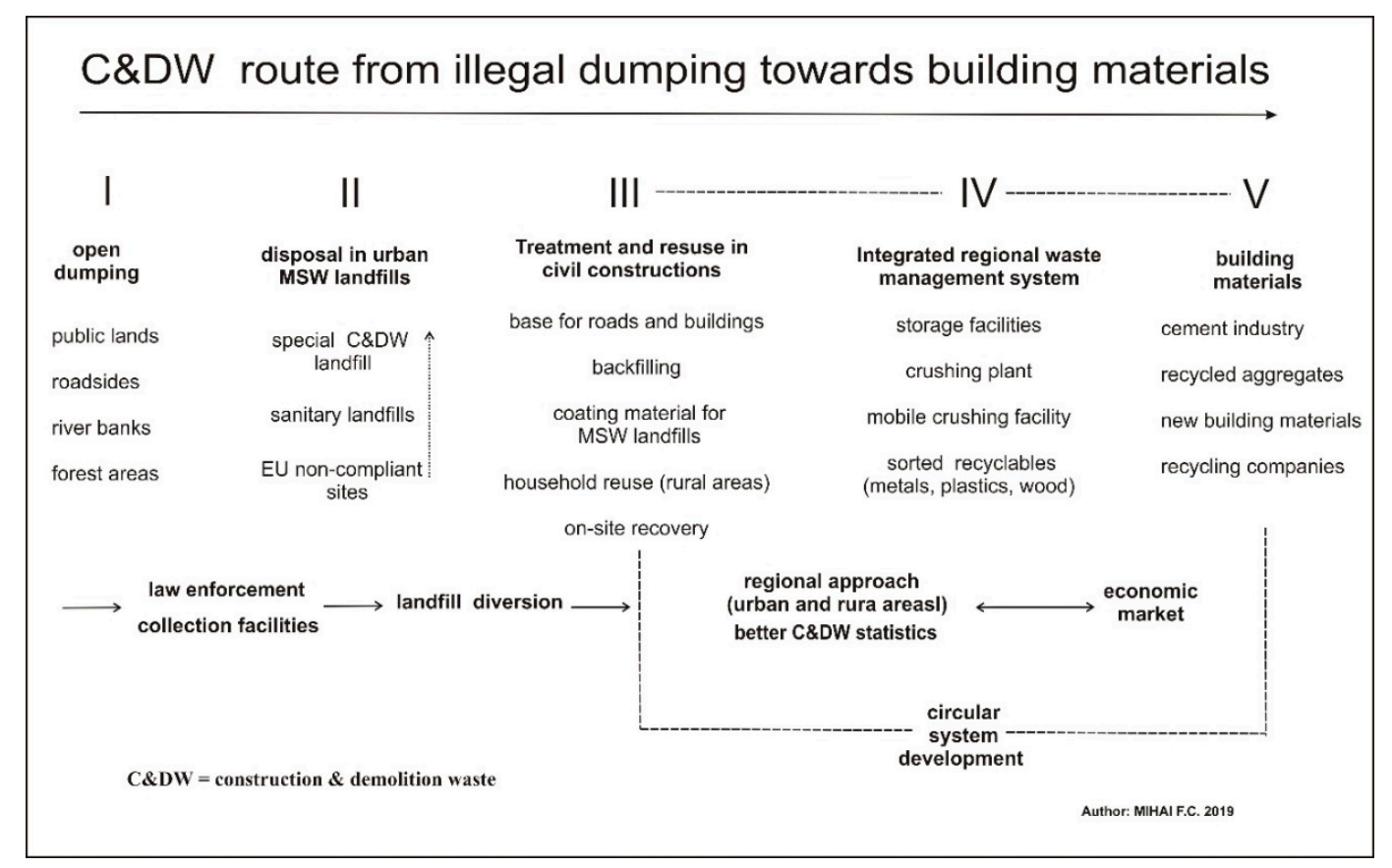

Figure 1. Development stages for a sustainable route of construction and demolition waste (C\&DW) management in Romania.

C\&DW collection schemes and storage facilities must be provided for all urban municipalities to combat illegal dumping issues in such areas supported by law enforcement under the supervision of the National Environmental Guard through County Commissariats. These basic actions are required for stage II.

Stage II represents the traditional waste management system based on landfill disposal where recycling and recovery potential of C\&DW fraction is lost, but open dumping practices are expected to decrease through the development of collection facilities. Urban landfills are rapidly filling up demanding new land areas for waste disposal sites. This practice supports a linear economy, which feeds natural resources depletion for the construction sector and C\&DW management is improperly performed, mainly in larger urban areas. Noncompliant urban landfills (with EU regulations) are replaced by regional sanitary landfills, which will serve both urban and surrounding rural communities. The best option is to provide special sites for $C \& D W$ stream avoiding contamination 
with municipal or industrial waste fractions. On the other hand, such sites will demand more land, which could be used for other economic sectors (e.g., agriculture).

C\&DW diversion from municipal solid waste (MSW) landfills is the key issue to stage III, where the circular system starts to emerge. On-site recovery, backfilling, based for roads, these are the main alternatives adopted by construction companies and waste operators. Crushing plants feeds the MSW landfills with the coating material. This is a widespread reuse option among waste operators. The transition from stage III to stage IV implies a regional approach of C\&DW complementary to MSW management infrastructure, which must be supported by better waste statistic database and proper monitoring activities. This is a key challenge for Romania due to the socioeconomic gaps between large cities compared to smaller urban areas and rural communities. The new regional integrated waste management systems (which cover an entire county) must provide basic facilities for C\&DW flows. Regional waste management systems must be operational in the following years, in each county, to provide reliable recycling and recovery alternatives for C\&DW fraction. In this context, stage $\mathrm{V}$ could emerge supported by a reliable economic market. This is a critical point to enable a circular economy system between the waste management sector and industry starting from stage III towards stage $\mathrm{V}$. The lack of market mechanism to aid a greater recovery was found as a critical challenge in UK industry sector to enable the transition towards circular economy [6]. Public policies should encourage the business sector to develop recovery technologies and capabilities and to promote partner networks to access secondary materials [7].

Such system will decrease the dependence on natural resources (e.g., aggregates) as raw materials for construction sector towards recycled items in a country like Romania with a great demand for infrastructure development (highways, improved railways, paved roads, public utilities, hospitals, residential buildings, etc.). Thus, C\&DW stream is expected to increase in the following years and sound waste management is required. Furthermore, this transition towards recycled building materials will reduce the prevalence of landfills and eliminating the open dumping practices as one of the primary disposal options in the stages I-II. The prospects of such a sustainable path are further examined according to each stage with particular challenges and issues.

Spatial analysis and thematic cartography are used to reveal, on the one hand, the geographical disparities in Romania about the collected amounts of C\&DW by waste operators and on the other hand, to highlight the poor monitoring process of C\&DW flows across Romanian counties.

This fact is supported by the comparative analysis between the estimated amounts of C\&DW generated by the urban population (calculated on per capita basis) compared to those collected by urban operators. Also, the ratio of C\&DW of total MSW collected by waste operators is determined for each county using the Jenks natural breaks classification method, which is specifically used for thematic cartography. This method enables the determination of the best arrangement of values into different classes by reducing the variance within classes and maximizes the variance between classes, highlighting the disparities between regions of a country on a particular theme or indicator [8].

The maps point out that this fraction is poorly covered by waste statistics even across urban areas. The paper provides a regional insight of C\&DW management activities in Neamt county, highlighting the gaps between larger cities, towns and rural communities. Amounts of construction waste are estimated based on usable floor area criteria for each city and town and compared to those collected by waste operators (based on data provided by the Environmental Protection Agency of Neamt County). Furthermore, this section reveals the uncontrolled waste disposal practices associated with the lack of collection and treatment facilities combined with a regional waste governance crisis and a poor economic market of recycled items resulted from the sole operational crushing plant in the county.

To combat such failures and to support the waste diversion from open dumps and MSW landfills, a circular system must be further developed in each county of Romania as suggested by stages III-V. Such incentives and current best practices are analyzed as pathways for sustainability in C\&DW management in Romania (see Section 3) supported by peer-reviewed literature. 
Also, various sources were consulted to analyze the state of art in C\&DW management activities in Romania such as the annual environmental reports of local environmental protection agencies (e.g., data for thematic maps at county level); technical reports for specific waste management infrastructures under the supervision of County Councils or local municipalities; reports and websites of construction and recycling companies, waste operators; data provided by National Institute of Statistics or Environmental Protection Agency of Neamt county (Section 3.4).

The regional approach of the C\&DW management sector involving both urban and rural municipalities must emerge in the following years to increase recycling and recovery rates at minimum $70 \%$ of total weight derived from construction and demolition activities stipulated by the Law No. 211 on waste regime [9].

\section{Construction and Demolition Waste Management Activities in Romania}

\subsection{Illegal Dumping of CEDW (Stage I)}

At the national level, there is a large number of non-compliant management situations for C\&DW, the majority consisting of their abandonment and/or uncontrolled storage on both intra- and extra-urban land [10]. Such practices are favored by the poor law enforcement of local authorities and the lack of landfills for this waste fraction [11]. Discontinuation of illegal, non-compliant, dumping or unauthorized landfilling will encourage a proactive approach of C\&DW generators in finding alternatives to landfilling [12]. Construction companies are responsible to transport the C\&DW generated to safe disposal facilities according to the "polluter pays" principle or to delegate a waste operator for such services.

At the household level, the C\&DW resulted should be transported by formal municipal waste management services towards recycling facilities or urban landfill sites. Waste collection coverage is still incomplete across middle and smaller cities with a poorer connection towards rural areas. This fact encourages the illegal waste disposal of C\&DW as shown in Figure 2. Frequently, wild dumps contain mixed waste fraction as C\&DW, municipal waste, and agricultural waste, particularly in rural areas. Field observations reveal that both urban and rural municipalities are exposed to illegal dumping issues of C\&DW. Periurban communities are most susceptible to such practices due to the expansion of urban areas.

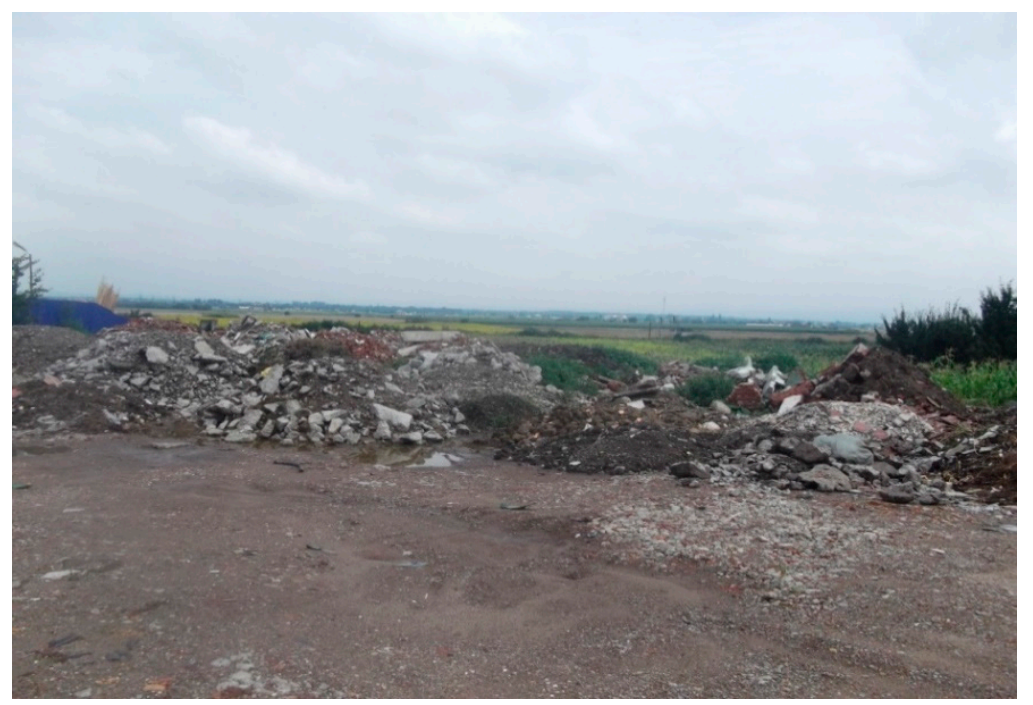

Figure 2. Illegal dumping of C\&DW in Hemeius commune, Bacau county (July 2014).

Also, regions of Poland are facing similar issues. Construction waste collection and transport is costly and it is often collected as mixed waste or is deposited in illegal dumping sites [13]. Uncontrolled waste disposal is still an environmental threat to be solved in Croatia [14] and in other European 
regions, there is a significant amount of illegal dumping combined with a heterogeneous market for secondary materials that may not be reflected in official statistics [5].

The illegal dumping of C\&DW poses financial issues for Romanian local authorities, which must provide cleaning activities of public lands from their local budget [15]. In rural areas, illegal disposal of C\&DW was a widespread practice due to the poor connection to reliable waste collection services prior to the closure of rural wild dumps during 2009-2010. The closure of such sites was required by Government Decision No. 345/2005 regarding the landfill of waste. Some rural dumpsites were closed and covered with C\&DW as a coating material. There are no data about the magnitude of illegal dumping issue at the national scale, which include both urban and rural areas. This paper draws attention to this issue by revealing the gaps in current C\&DW flows and the geographical dimension of uncovered data by waste operators, which could be used (in further studies) as a proxy indicator for regional or national assessments of illegal dumping practices.

Local C\&DW generated at the household level are partially collected by waste management services or reused as filing material for local unpaved roads, household base.

The lack of storage facilities and long distances to treatment plants makes the transport to be less cost-effective encouraging the stakeholders to adopt illegal waste disposal practices.

\subsection{CEDW Collection and Disposal in Urban Landfills (Stage II)}

C\&DW collected by waste operators is frequently disposed of in municipal waste landfills or non-hazardous industrial landfills, which mitigate their initial disposal capacity. The acceptance of this fraction to be disposed of in municipal waste landfills at lower costs mitigates the development of recycling and recovery activities [11].

C\&DW generated from Constanta County have been disposed of in a special landfill site located in Ovidiu town since 2008 (capacity-310.767 $\mathrm{m}^{3}$, first phase). Gurau et al. [16] reveal that, in this county, only $13.56 \%$ of C\&DW $(15,220 \mathrm{t})$ was collected in 2008 compared to $122.250 \mathrm{t}$ estimated to be generated by the regional waste management plan of the South-East region. Furthermore, in 2009, 2006.6 t of $6850 \mathrm{t}$ C\&DW collected in Constanta county was disposed of at this site. The availability of data concerning the C\&DW flows is limited in Romania. Such data are provided mainly by urban waste operators based on volumetric estimations and aggregated at the county level by the local environmental protection agencies (EPA). The volume data (based on waste truck capacity) are transformed in metric tons using a specific density of $2 \mathrm{t} / \mathrm{m}^{3}$ as suggested by environmental authorities. The waste operators are obliged to send such waste statistics data to local environmental protection agencies.

The C\&DW data is aggregated at the county level (equivalent to EU NUTS 3 regions), but lacking at local administrative unit levels (cities and communes). Noncompliant landfills have no weighing systems and most of waste statistics data rely on such volumetric estimations. On the other hand, there are no strict regulations to oblige construction companies to provide data about the C\&DW flows. Most of the C\&DW generated are managed by such companies. In this context, data gathered by environmental authorities are still very poor and highly underestimated [12]. A general lack of data on waste management practices is seen at the global level, which affects the measurement of C\&DW performances across various economies [17]. Data about C\&DW flows requires special attention because this fraction is disposed both legally and illegally and frequently is not recorded as a separate waste stream, or is recorded incorrectly [18].

The quantity of C\&DW increased in 2003-2008 due to the fast development of the construction field followed by a regress caused by the economic crisis, which started in 2009 [19]. Construction sector generated $5.7 \%$ of GDP in 2002, and $10.5 \%$ in 2008, with a peak of activity in 2007 when 45,867 new habitations were completed (most of them in Bucharest city and Ilfov county) [20].

$C \& D W$ sector is expected to increase in the following years due to the Romanian emerging economy and serious needs for infrastructure development.

The interviewed stakeholders pointed out that the lack of infrastructure to store, treat, and recycle C\&DW is a huge problem in Romania [12]. Figure 3 reveals the regional disparities across 
Romanian counties regarding the ratio of C\&DW of total municipal waste collected in 2014 using the Jenks natural breaks classification method. Local environmental reports provide the data concerning C\&DW amounts collected by waste operators in each county, then, the ratio of this waste stream of total municipal solid waste collected (by public or private waste operators) is further calculated at county level.

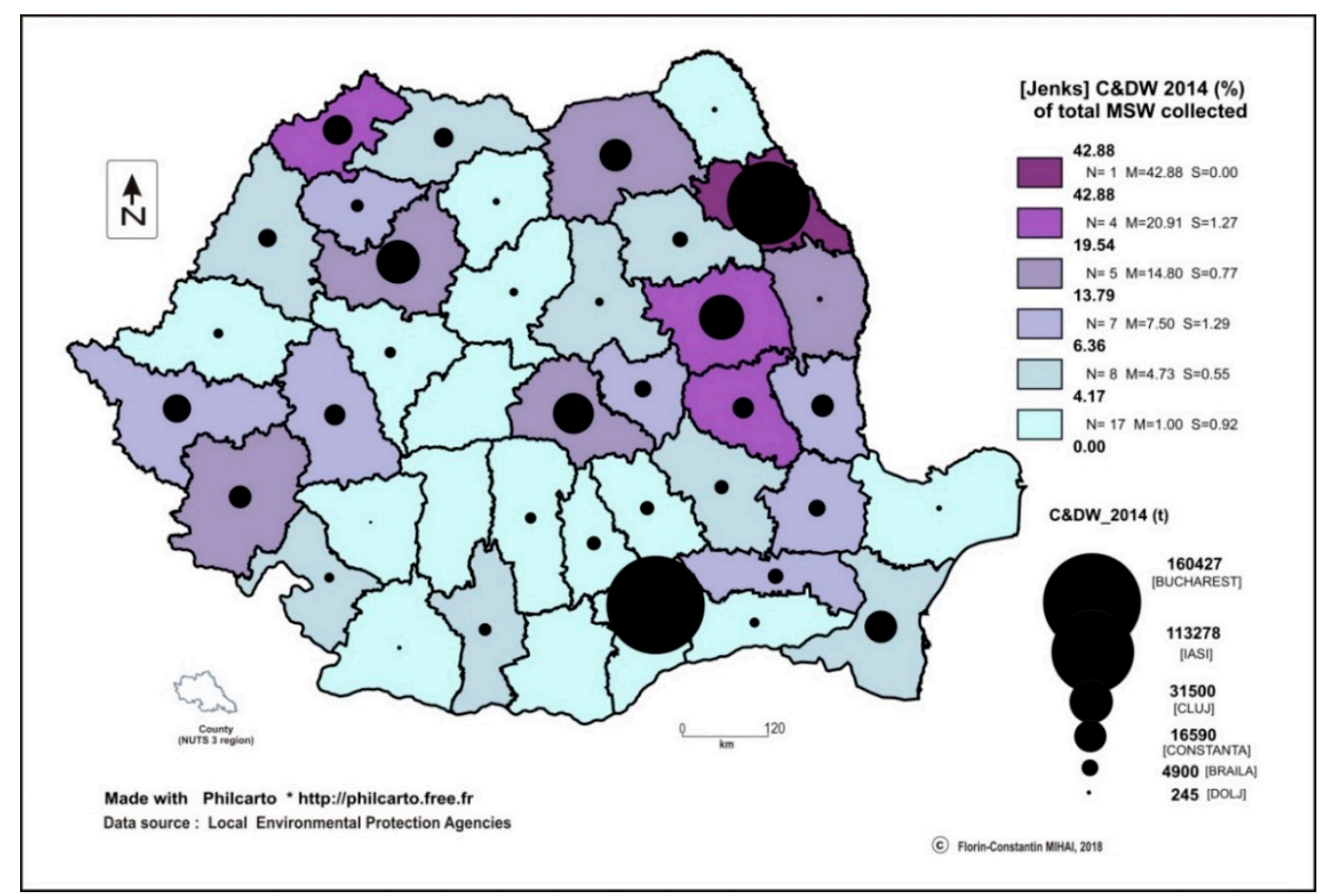

Figure 3. The ratio of C\&DW collected by waste operators from total municipal solid waste (MSW) (2014).

The paper provides the first assessment of regional gaps of C\&DW flows in Romania using spatial analysis. This approach better reveals the magnitude of poor statistics related to the amounts of C\&DW collected by waste operators. Furthermore, this study shows major differences between the C\&DW generated in urban areas (calculated on a per capita basis) compared to those collected by waste operators These findings suggest serious challenges to evaluate the progress made by Romania so far taking into account the current regional disparities as shown by the maps (Figures 3-5).

Large amounts of $C \& D W$ characterize the major urban areas with a strong demand for construction activities (residential buildings, offices) such as Bucharest city, Iasi and Cluj counties where C\&DW fraction has over $13.8 \%$ of total waste collected compared to other counties (e.g., Dolj, Gorj, Tulcea, Bistrita-Nasaud) where this fraction is barely noted (please check this map for the names of counties https://en.wikipedia.org/wiki/Counties_of_Romania). In fact, the ratio of C\&DW fraction is below $4 \%$ in seventeen counties, most of them located in the center and southern part of Romania. The same poor registered quantities of $C \& D$ waste at the county level are found in Croatia, particularly in less developed areas [14].

Figure 3 suggests that monitoring process of C\&DW flows is limited in these areas which could increase the risks associated to illegal waste disposal practices and the prevalence of stage I. In other cases, the share of C\&DW could be significant (between 6.39-13.8\%) outlining an emerging construction sector in eight counties of Romania (e.g., Suceava, Bacau, Timis, Satu Mare).

The second map (Figure 4) reveals the major gaps at the national level concerning the proper monitoring of C\&DW flows. 


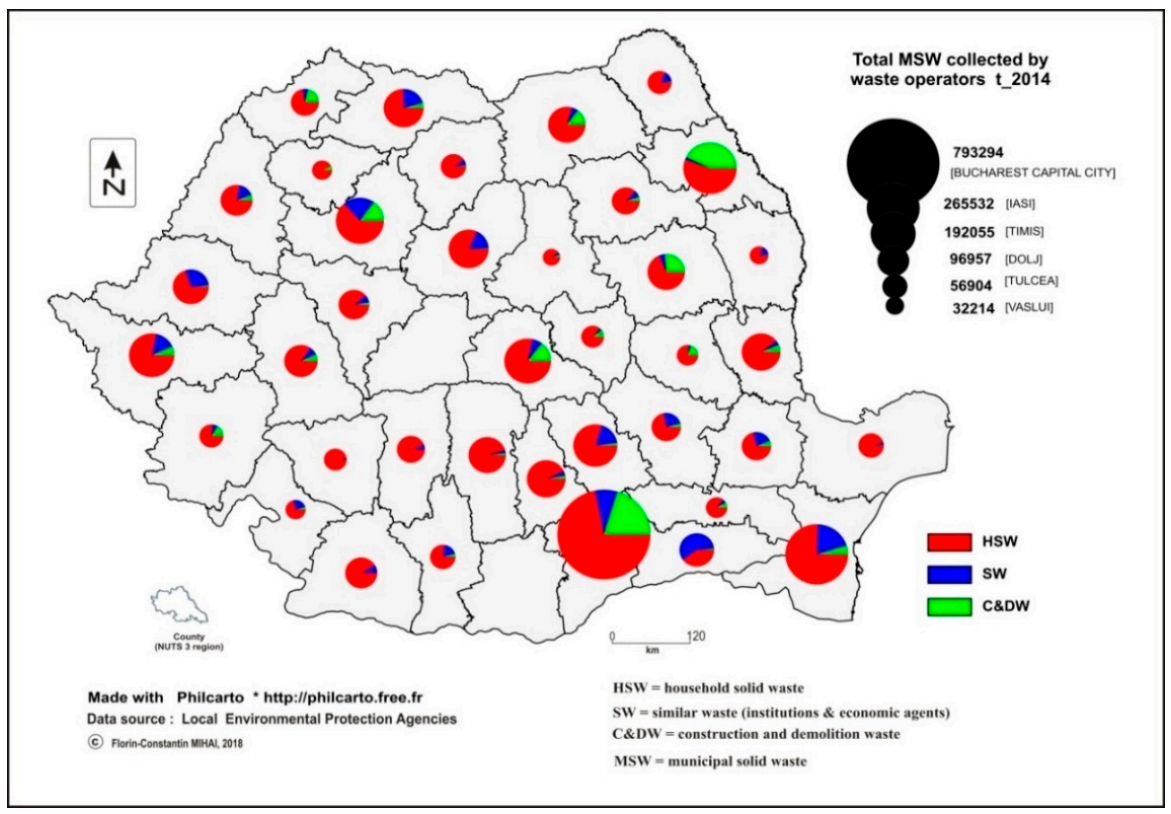

Figure 4. Amounts of household, similar and C\&DW collected by waste operators in $2014(\mathrm{t})$.

This situation is explained by the fact that waste operators are the main data providers for local environmental reports. There are counties, which do not report any data of C\&DW collected in 2014 such as Sibiu, Teleorman, Giurgiu counties, or in other cases, the data are not updated (before 2014). Several counties reported small amounts of C\&DW collected under $1000 \mathrm{t}$ such as Botosani, Vaslui, Gorj, or Dolj. Bucharest city has 1.883 million inhabitants and it is the main industrial and commercial center of Romania with great interest in the construction sector. This explains a large amount of C\&DW collected (160,427 $\mathrm{t}$ of total 793,294 $\mathrm{t}$ municipal solid waste) by urban waste operators in 2014 as shown in Figure 4.

Iasi County has the largest amount of C\&DW collected (113,278 t), followed by Cluj $(35,000 t)$ On the other hand, Iasi County has the highest ratio of C\&DW from total MSW collected (42.88\%, see Figure 3) compared to Bucharest capital city (20.23\%).

Figure 4 points out the fact that waste operators provide insufficient data concerning the magnitude of C\&DW flows across Romanian counties. Their activity focuses on collecting municipal solid waste stream consisting in household waste (residential areas) and similar waste fraction generated by institutions, economic agents (shops, offices, hotels, restaurants, etc.) and industrial sector. Thus, construction companies handle most of these C\&DW flows without concrete data about their management and disposal practices.

However, Figure 4 shows regional differences in total MSW collected which is also expected in case of C\&DW stream due to several potential factors such as population, urbanization rate, socioeconomic status, urban centers, real estate market, industrial development, etc.

In emerging economies, the share of construction waste is $40 \%$ of total municipal waste, which account over 200 million tons in China [21].

The paper estimates the amounts of C\&DW in urban areas of the Romanian counties using a per-capita waste generation rate of $280 \mathrm{~kg}$ per-capita $\mathrm{yr}^{-1}$ as suggested by Musuroaea et al. [10]. It should be noted that this value does not include the major infrastructure projects such as new roads, railway rehabilitation, and large industrial facilities.

The third map (Figure 5) aims to reveal the underestimation level of C\&DW at national and county level resulted as the difference between the total amounts of C\&DW collected by waste operators in 2014 (data provided by local environmental reports) and those generated by urban areas (applying the mentioned per-capita waste generation rate). 


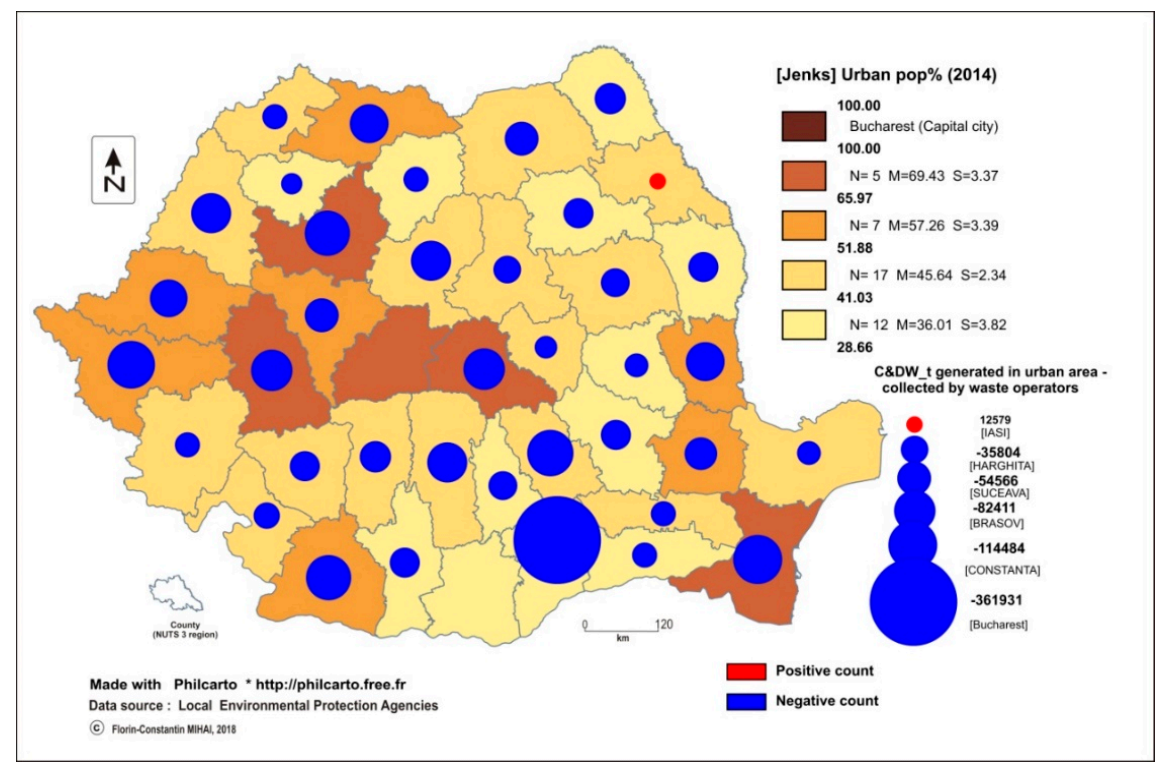

Figure 5. Comparative analysis between CDW generated in urban areas (per-capita basis) and those collected via waste operators (2014).

The results show that waste operators collected 519,723.36 $\mathrm{t}$ in 2014 compared to 2,925,333.88 $\mathrm{t}$ of C\&DW estimated to be generated across urban areas. In other words, the paper points out that only $17.76 \%$ of C\&DW generated in urban areas is actually collected by waste operators. The rest is mainly managed by construction companies or by individuals using on-site recovery (stage III), own transportation to urban landfills (stage II) or illegal disposal practices in periurban communities (stage I). Urban areas are the main generators of C\&DW at the county level in comparison to rural areas. The treatment facilities of $C \& D W$ are mainly in urban areas where large construction companies operate.

There are no special plants for the treatment of hazardous C\&DW fraction estimated at $4 \%$ of the total waste stream [6]. This fact increases the pollution risks if such materials are not collected and disposed of in proper facilities.

Figure 5 reveals a poor monitoring process of C\&DW flows at the urban level across the country.

Small-scale constructions (residential buildings) and public works (various infrastructures) are approved based on the building permit and the owners should take the responsibility for C\&DW generated. This study reveals that thousands of tons of C\&DW may be susceptible to illegal dumping if not properly managed by each generator (individual or business sector). Neither county with a higher urbanization rate ( $>65 \%$ of the total population) have proper monitoring of C\&DW flows (Constanta, Brasov, Hunedoara). Furthermore, urban areas could generate significant amounts of C\&DW even in counties, which have a ratio of C\&DW below $4 \%$ in the total waste stream, collected by waste operators in 2014 (see Figure 5 vs. Figure 3).

Despite the fact, Bucharest city has the largest amount of C\&DW collected, there are 361,930.64 t of C\&DW uncovered by environmental reports as shown in Figure 5.

This situation is due to the lack of clear regulation on how this waste stream should be managed and how all stakeholders should report the statistical data involved in the construction sector towards environmental authorities.

As an example, in Valcea County, no C\&DW is reported to be collected during 2014, but 45,621.52 t are estimated to be generated in urban areas. Large amounts of C\&DW are estimated to be generated in counties without data reported such as Sibiu (73,935.96 t). The negative counts (blue circles) are widespread across Romanian counties suggesting serious gaps in the waste statistics. There are several counties where over 100,000 $\mathrm{t}$ of $\mathrm{C} \& \mathrm{DW}$ generated are not found in the amounts collected and reported to environmental authorities such as Constanta $(114,483.88 \mathrm{t})$, Timis $(105,919.62 \mathrm{t})$, between 75,000-10,000 t (Dolj, Prahova, Arges, Brasov, Mures). 
Iasi county is the sole region with a positive count (red circle on the map) which means that all C\&DW estimated to be generated seems to be covered by those collected. This situation is explained by the large-scale works in the road infrastructure (e.g., the rehabilitation of tram lines) in Iasi in previous years, the continuous development of the residential construction sector (houses, villas, blocks) and offices, resulting in large quantities of asphalt waste from the excavation: soil, stones, gravel, mixtures of C\&D waste [22]. Most of such wastes are destined to the landfill site, but also illegal disposal sites were observed in the field across peripheral areas. Even in this favorable case, there are still C\&DW flows unaccounted by official statistics. This is the reason why a reliable quantitative estimation of stages I-III is difficult to proceed at local or regional levels.

Simion et al. [18] propose as the most appropriate C\&DW management option in Iasi city (in terms of ecological footprint) a scenario which implies temporary storage, collection, and transport than a line of sorting and recycling combined with landfill with leachate treatment. This scenario is already operating in other cities (e.g., Piatra Neamt) as part of the integrated waste management system, which includes a sorting station, crushing plant for C\&DW, and sanitary landfill. Urban landfill sites or wild dumps (on public or private lands) are widespread disposal options for this waste stream. In some urban areas, an alternative option is the storage of this waste stream in local temporary sites (C\&DW site), collection and transport services provided by waste operators or construction companies.

\subsection{CEDW Treatment and Reuse in Civil Construction (Stage III)}

The main practices currently engaged in the recovery of C\&DW are backfilling or landscaping, mainly using inert waste (non-hazardous, such as sand, gravel, concrete, bricks, tiles, etc.) that is usually crushed [12]. At the national level, there are 31 crushing plants with a total capacity estimated at 3 million tons per year managed by authorized economic agents [11]. Some municipalities developed their own construction waste management services through pilot projects in Buzau (Buzau county), Medias (Sibiu county-public utility), Dej (Cluj county-public utility).

Fixed crushing plants are implemented as part of the integrated urban waste management system (e.g., Piatra Neamt city). However, there are several counties without any crushing plants where C\&DW is disposed of in urban landfills or scattered via illegal dumping sites across periurban and rural areas (e.g., Arad, Suceava, Satu Mare, Dolj, Teleorman, Tulcea, Hunedoara, Brasov Gorj, Valcea, Ialomita, Calarasi, etc.). The recycling rate of C\&DW has increased from 28\% in 2010 to 59\% in 2014, and the filling rate ranging between $11-14 \%$ [11].

These values are related to the total amount generated and collected, but in reality, the amounts of C\&DW generated are much larger than those collected in official statistics which ultimately affect the reliability of such data. The monitoring process of this waste stream is quite challenging for most of the European countries [5].

Landfill cover is another widespread practice for the inert fraction of C\&DW. Such practices are also stipulated in environmental reports. Most of non-hazardous C\&DW collected is used as backfilling and landfill cover material in Salaj County [23].

In Dambovita County, a decreased trend of the C\&DW ratio is observed (related to total waste collected by operators), from $9.14 \%$ in 2009 to $2.37 \%$ in 2014 associated with to the reuse of this waste stream as filling material [24].

According to the Waste Framework Directive (Directive 2008/98/EC) Romania must prepare for re-use, recycling and material recovery of non-hazardous C\&DW to a minimum of $70 \%$ by weight in 2020 [25]. This target will difficult to achieve without specific legislation for C\&DW fraction and poor coverage of crushing plants combined with a lack of storage facilities in each urban area.

\subsection{CEDW Management Activities in Neamt County—A Regional Case Study}

Neamt County is located in the North-East Region of Romania, which covers five cities and 78 communes (rural municipalities) with a total population of 470,766 inhabitants according to the latest population census in 2011 


\subsubsection{Urban Areas}

Piatra Neamt is the county capital city and the sole urban area within Neamt County where a fixed crushing plant is operating [26]. This facility (capacity of 15,000 $\mathrm{t} / \mathrm{yr}$ ) is located in the proximity of composting plant and sanitary landfill avoiding supplemental transportation costs. Crushed waste, resulting from the plant, has been primarily used as the coating material (drainage layer) of the old landfill (during the rehabilitation process) then as a covering material for the first cell of the sanitary landfill (closed in 2010). The average of C\&DW processed is $1300 \mathrm{t} / \mathrm{yr}$ under $10 \%$ of plant capacity (8.6\%) [27]. In 2015, about $3670 \mathrm{t}$ of coating material was used for cell No. 2 within the sanitary landfill area. This fact suggests that this crushing plant could expand the geographical coverage area across the Neamt County. Piatra Neamt city has two separate collection centers located in Maratei and Darmanesti districts where C\&DW fraction is collected in special containers (included bulky items).

The individual or economic agents can dispose of their C\&DW to such centers or transport them to the sanitary landfill facility, which includes a temporary storage site for such wastes to be further processed by the crushing plant. Also, they can order a special container from the urban waste operator. Similar separate collection facilities for C\&DW are initiated in Poland cities [28]. On the other hand, Zagreb city has the sole stationary treatment facility; while in the other parts of Croatia recycling is carried out in mobile processing plants [14].

The sanitary landfill site of Piatra Neamt city has a weighing system, which is operational since 2007. The data about $C \& D W$ are more reliable than in previous years or in comparison with other urban areas where data are reported by waste operators based on volumetric estimations. Urban waste operators collected 72,488.9 t of C\&DW during 2004-2010 in the Piatra Neamt city, of which $49,092 \mathrm{t}(67.72 \%)$ between 2007-2010. This fact is explained by the contribution of old industrial sites demolitions within the administrative area of the city.

The construction wastes (CW) derived from the new residential buildings are estimated at each urban level based on the total usable floor areas (UFA) resulted from building authorizations as applied to rural communities in a previous study by Mihai and Grozavu [29]. A waste generation rate (WGR) of $21.38 \mathrm{~kg} / \mathrm{m}^{2}$ per net usable floor areas $\left(\mathrm{A}_{\mathrm{ufa}}\right)$ is used based on the HQ Air Force Center for Environmental Excellence recommendation [30].

$$
\mathrm{Q}_{\mathrm{cw}}(\mathrm{t})=\mathrm{A}_{\mathrm{ufa}}\left(\mathrm{m}^{2}\right) * \mathrm{WGR}\left(\mathrm{kg} / \mathrm{m}^{2}\right) / 1000
$$

The same approach is performed to estimate the C\&DW flows in Thailand, because this country is facing similar issues in terms of poor reporting system associated with this waste stream [31]. Unreliable estimates lead to inadequate policies and unsound waste management practices in emerging economies like India [32]. European countries deal with same challenges and new approaches are required to provide better estimations of C\&DW flows in different construction stages [33] or to examine the spatial trend of building material stock and potential demolition wastes including the analysis of historical maps [34].

In this study, data concerning the number of private buildings, new buildings with associated usable floor areas are provided by the National Institute of Statistics (INS) via tempo-online database [35] The amounts of CW generated by these buildings are determined using the above equation and compared to the amounts of C\&DW collected by waste operators. Some urban areas are served more than one waste operator. In the latter case, data are aggregated at each city level based on information received by EPA Neamt from urban waste operators.

Table 1 points out that Piatra Neamt and Roman cities collected the most significant amounts of $C \& D W$ in Neamt county which significantly exceeds those resulting from new residential areas. 
Table 1. Construction and demolition wastes (C\&DW) collected by urban waste operators and construction wastes (CW) generated from new residential buildings during 2004-2012.

\begin{tabular}{ccccccc}
\hline $\begin{array}{c}\text { Urban } \\
\text { Areas }\end{array}$ & $\begin{array}{c}\text { Pop. 2011 } \\
\text { (Census) }\end{array}$ & $\begin{array}{c}\text { Private Buildings } \\
\mathbf{2 0 1 2}(\mathbf{N r})\end{array}$ & $\begin{array}{c}\text { New Buildings } \\
\mathbf{( 2 0 0 4 - 2 0 1 2 )}\end{array}$ & $\begin{array}{c}\text { Usable Floor } \\
\text { Areas (sq.m) }\end{array}$ & $\begin{array}{c}\text { CW } \\
\text { Generated (t) }\end{array}$ & $\begin{array}{c}\text { C\&DW } \\
\text { Collected (t) }\end{array}$ \\
\hline Piatra-Neamt & 85,055 & 42,919 & 858 & 159,660 & 3413.53 & $78,614.6$ \\
Roman & 50,713 & 25,774 & 576 & 87,569 & 1872.23 & 6486.06 \\
Bicaz & 6543 & 3417 & 279 & 31,349 & 670.24 & 100 \\
Roznov & 8593 & 3546 & 401 & 51,763 & 1106.69 & 0 \\
Targu Neamt & 18,695 & 7732 & 496 & 85,156 & 1820.64 & 117 \\
\hline Source of data: INS Tempo-online (private buildings, new buildings, UFA), EPA Neamt (C\&DW collected) and own \\
calculations (CW).
\end{tabular}

On the other hand, poor C\&DW is reported to be collected in Bicaz and Tirgu Neamt and none in Roznov town. In the latter case, this town was not covered by an effective formal waste collection service prior to 2010. Furthermore, Targu Neamt and Bicaz towns no reported any C\&DW collected during 2011-2012. Poor waste management facilities in these towns favored illegal waste disposal practices on the surroundings. C\&DW fraction is susceptible to such practices because almost $3380.57 \mathrm{t}$ of CW are not covered by official records in Tirgu Neamt, Bicaz, and Roznov towns. At the county level, the amount of C\&DW collected by waste operators decreased from $3688.35 \mathrm{t}$ in 2014 to $1068.64 \mathrm{t}$ in 2015 [36].

This fact could suggest that most of the construction companies perform their activities without environmental permits and without providing official reports regarding C\&DW flows. Furthermore, the EPA Neamt report [36] points out that treatment facilities of the Piatra Neamt city (composting and crushing plants) have serious issues in selling the secondary materials (compost and recycled aggregates) during 2009-2015.

Because of this economic market crisis, large amounts of treated C\&DW have been accumulated on storage sites. The crushing plant continued to operate in 2014-2015 despite existing stocks while, the dry recyclables processed by the sorting facility (metals, paper \& cardboard, plastics, and glass) have been sold to economic agents. There is a significant difference between the amounts of C\&DW collected during 2011-2012 in Piatra Neamt such as $6125.7 \mathrm{t}$ (of which $3768.1 \mathrm{t}$ from economic agents) and treated via crushing plant compared to Roman city where all of C\&DW collected $(523.32 \mathrm{t}$ of which $496 \mathrm{t}$ provided by economic agents) were disposed in the noncompliant landfill. There is a poor economic market related to C\&DW fraction in Neamt County so far because the natural aggregates are abundant across the county through the presence of several gravel sites on river meadows. Additionally, there is a limestone quarry in the Eastern Carpathians (Bicaz-Chei commune) and a marl quarry (Bicazu-Ardelean commune) that provides the raw materials to the cement factory (Heidelbergcement) located in Tasca commune, near to Bicaz city. Frequently, the economic agents of the construction sector run activities that are not environmentally authorized and therefore, do not comply with construction waste recycling targets or have the necessary documents for the transport of wastes [36]. This situation leads to uncontrolled waste disposal practices on public lands across urban and rural areas. Better law enforcement is required from both local councils and local environmental guard. Such practices can be further monitoring combining field data and GIS tools [37] in comparison with official statistics.

\subsubsection{Rural Areas}

No special waste collection services dedicated to C\&DW are generally provided. The wastes generated at the household level are either illegally disposed on the surroundings or inert fraction is reused as a base material for new buildings, backfilling local unpaved roads.

Frequently, the wood fraction is recovered as solid fuel, and metals are collected to be sold to recycling companies. Some rural municipalities are not fully covered by waste collection services and the illegal waste disposal practices, including C\&DW fraction, is still detected across rural areas [38]. Some of C\&DW items are disposed of in sturdy bags or residual containers to be collected by waste operators and transported to urban landfills. 
However, there is a waste operator that serves rural municipalities exclusively (e.g., Savinesti, Pipirig, Faurei, Ruginoasa communes). This operator collected 188 t of C\&DW in 2011 (from economic agents) and $288 \mathrm{t}$ in 2012 (population); this debris being disposed of to the Roman city landfill site according to EPA Neamt data.

Rural communities are exposed to illegal disposal of C\&DW performed by construction companies. Field observations revealed such bad practices on local roadsides, pastures, floodplains and river banks as shown in Figure 6.

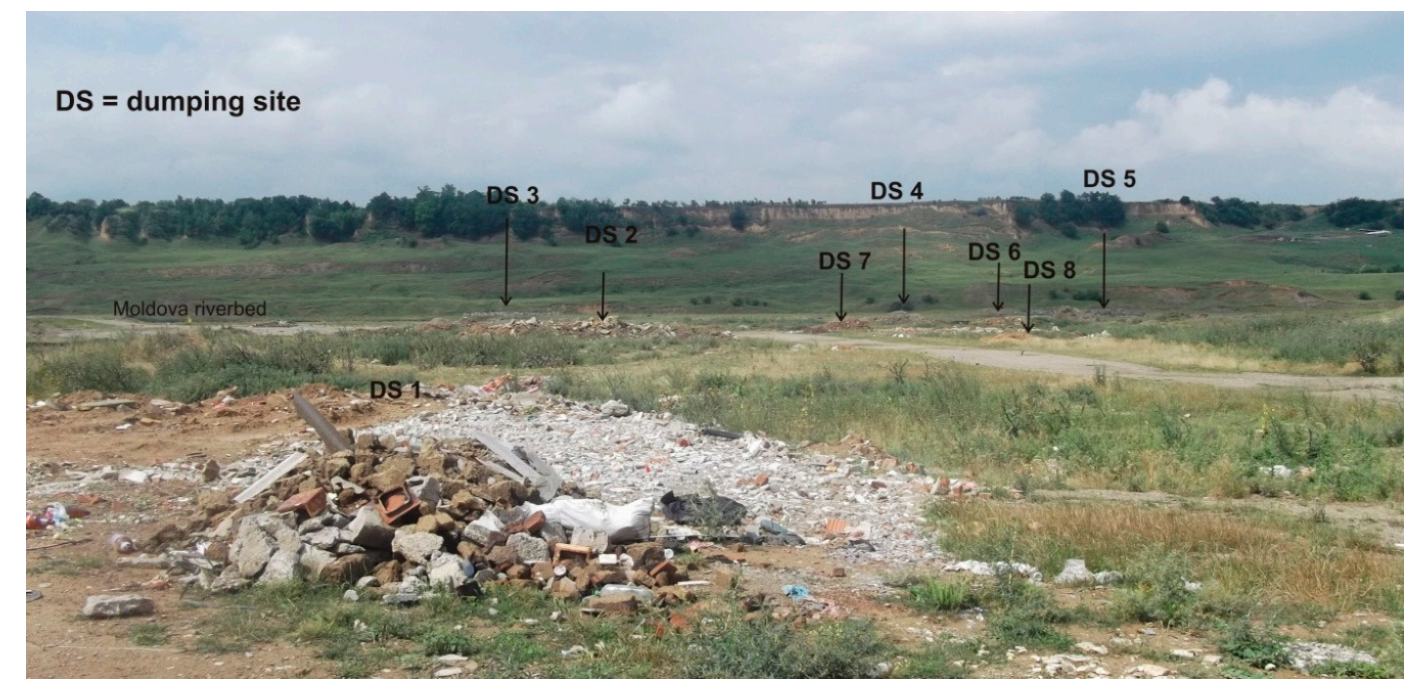

Figure 6. Several C\&DW dumping sites on Moldova floodplain (Pildesti village, July 2014).

Mihai and Grozavu [29] estimated that 31,393 $\mathrm{t}$ of construction waste has been generated by rural buildings at the county level (during 2002-2010) of which $4897.3 \mathrm{t}$ recyclables, $9417.9 \mathrm{t}$ bricks, and tiles, and $2197 \mathrm{t}$ concrete. The values are raging between 1000-2000 $\mathrm{t}$ in periurban localities with the highest interest in residential buildings or touristic pensions to lower than $100 \mathrm{t}$ in the poorest regions of the county. These wastes either are disposed of in open dumps or reuse and recovered at the household level

Rural communities face similar changes nowadays due to the lack of proper collection and storage facilities associated with the construction sector. Thus, the stage I still prevails in rural regions of Neamt County. Furthermore, the regional sanitary landfill site located in Girov commune (which should cover most of the urban and rural municipalities across the county) has been opened later (since August 2015) due to the prolonged delays caused by a tender process regarding the management of this site.

Thus, temporary storage sites (basically dumpsites) replace the old noncompliant landfills (closed on July 2012) as the primary waste disposal option of wastes collected (including C\&DW fraction as a separate waste fraction or residual mixed waste) in Tirgu Neamt, Roman, Bicaz, and Roznov cities and surrounding communes.

These temporary sites should be closed and all the wastes accumulated to be transported to the Girow sanitary landfill, but this implies other costs for waste operators and municipalities. On the other hand, construction companies and local waste operators try to avoid the sanitary landfill fees looking for cheaper waste disposal alternatives.

Illegal dumping of C\&DW still occurs within the study area due to this waste governance crisis. Further investigations are needed to reveal the magnitude of environmental threats associated with the lack of C\&DW management activities including other rural regions of Romania. 


\section{Pathways for Sustainability in C\&D Waste Management in Romania}

\subsection{Development of Recycling and Recovery Centers in Urban Areas (Stage IV)}

General guidelines about C\&DW issues are released at EU level using a life-cycle thinking approach [3]. In Romania, a guideline of best practices in the management of C\&DW has released in 2011 as part an integrated waste management project in Center Region (NUTS 2) between regional and local Norwegian and Romanian authorities [39]. Throughout this project, Medias city has implemented a recycling and recovery center dedicated to $C \& D W$ fraction. Individuals or economic agents may require a special container for C\&DW fraction. The waste operator transports the container to the recycling and recovery facility or the C\&DW generated are brought by each generator. The C\&DW are sorted via a mechanical process resulting in new materials for reuse in the construction sector. In 2016, this facility collected and processed $4278.5 \mathrm{t}$ of C\&DW and it received 394 orders for waste collection services [40]. To have a building permit, the individuals or economic agents have to report the resulted C\&DW quantities and to stipulate how they manage this debris. This could be a key aspect in preventing the illegal dumping of C\&DW around the periurban areas. Local public authorities could implement such recycling and recovery centers through own projects correlated with the local needs without any further governmental interventions. The Life project LIFE10 ENV/RO/000727 “Recovery of construction and demolition waste in Buzău county/VAL-C \& D", provides a critical pilot research area related to C\&DW management activities at Buzau county level [10]. There is a pilot station for mechanical treatment (crushing) and, where appropriate, gravimetric sorting of C\&DW which has a maximum treatment capacity of 40,000 t/year, respectively $20 \mathrm{t} /$ hour (http://www.domeniiprestserv.ro/despre-noi.html). The main operations performed at the recycling facility [41]:

- The C\&DW are screened at the weighing system in order to record the waste fractions, which are accepted for crushing plant.

- The wastes are disposed into a temporary storage area;

- The recyclables are sorted (wood, paper, and cardboard, metals, glass, plastics, tiles, etc.);

- Cutting beams and other large reinforced concrete elements;

- Primary crushing with the jaw crusher;

- Magnetic separation of metals;

- The pick secondary crushing;

- Manual selection of wood, plastic, paper, and cables;

- Sieving by particle size fractions;

- Granulometric classification $(0 / 10 \mathrm{~mm}, 10 / 30 \mathrm{~mm},>30 \mathrm{~mm})$;

- Removal of the tiny particles by filtration, washing;

The project is a public-private partnership that aims to promote sound management of C\&DW fraction. In order to encourage the recycling and recovery operations, this facility charges a fee (50 RON, $1 \mathrm{EUR}=4.7 \mathrm{RON}$ ) for the use of weighing system not per ton of C\&DW disposed of.

In 2015, this facility processed $1200 \mathrm{t}$ of C\&DW and all resulted building materials were sold while in 2016, $1500 \mathrm{t}$ C\&DW were processed of which 280 were sold (photo gallery http://www. domeniiprestserv.ro/galerie-foto.html) [41].

A concrete crushing plant has been inaugurated in December 2010 which aims to treat the C\&DW generated and collected from the metropolitan area of Oradea city (Bihor County). Thus, the concrete crushing plant ECO BIHOR SRL offer several options regarding the C\&DW treatment services (https://ecobihor.ro/beton.htm) [42]; (i) Recycling as a service provider; the customer keeps the finished product (crushed concrete, iron); (ii) partial recycling where the customer keeps the iron separately after crushing and the crushed concrete is preserved by ECO BIHOR; (iii) treatment of demolition waste where the finished product is preserved by ECO BIHOR (crushed concrete, iron).

These examples mentioned above points out the first steps of a sustainable approach of C\&DW in Romania which must be further developed in each urban area. 


\subsection{Extension of Waste Co-Processing Activities in Cement Industry (Stage V)}

Waste fractions are used in the cement industry in the co-incineration process as a substitute for fossil fuels and material recycling as a substitute for raw material in cement production. There are seven cement factories in Romania authorized to co-incineration process which use various waste streams: sorted municipal waste, used tires, refused-derived fuels (RDF), oils, hazardous and non-hazardous industrial wastes, etc. These cement factories located in Deva, Bicaz, Fieni (Heidelberg Cement Romania), Alesd, Campulung (Holcim Romania), Medgidia, Hoghiz (CRH Cement Romania) have integrated the clinker manufacturing process. In order to obtain the composite cement, the clinker is partially substituted by other mineral compounds with similar chemical characteristics as natural materials (limestone) or residual such as C\&DW or secondary materials (granulated blast furnace slag, fly ash). Co-processing waste is widely applied by the cement industry worldwide and recognized at European level as one of the best practices of efficient use of resources [43]. Cement and concrete industry from Romania may lead to this transition by expanding co-processing waste facilities. As an example, Holcim Romania claims to invest 3 million Euro in expanding its co-processing facilities in its cement plants in Aleşd and Câmpulung [44].

The amount of industrial and municipal waste co-processed in the cement industry from Romania during 2004-2014 is 2 million tons, which is equivalent of municipal waste generated in a year by 24 cities with over 250.000 inhabitants [43].

The key aspect is to increase the role of inert C\&DW fraction as a material substitute in cement production. The experiments reveal that the materials with industrial waste such as ultrafine fly ash are recommended to be used as prefabricated slabs for the pavement [44].

Cement concrete of CDW is also suitable for pavement construction. Laboratory tests showed that recycled aggregates had similar performance characteristics with crushed gravel as chippings used in rigid pavement construction [45].

Cement production and recycled aggregates are important routes for recycling and recovery of C\&DW in Romania, which must be further developed. Waste and byproducts of other industries replace $20-30 \%$ of traditional natural raw materials used by the cement industry and save over 2 million tons of natural resources annually [46].

\subsection{Development of Recycled Aggregates Sector (Stage V)}

The valorization rate of recycled aggregates resulted from the mechanical treatment of C\&DW via crushing plants is still insignificant in Romania.

The costs of such practices are too high in comparison with natural aggregates and there are still few crushing plants at the national level [11]. Romania is very rich in mineral aggregates, and no incentives are created to prefer recycled and more expensive aggregates [12]. Annually, approximately 25-30 million cubic meters of natural aggregates of sedimentary origin (sands and gravel) are extracted by excavation either from the river beds or from the terraces of the meadows [47]. Each city should be served by a fixed or mobile crushing plant in order to recover the C\&DW generated and avoiding illegal or legal landfill practices. These plans may be incorporated under the regional waste management system that should cover both urban and rural areas of the county.

The inert fraction of C\&DW is favorable for the production of aggregate $0 / 30 \mathrm{~mm}$ as supported by an LCA analysis from both environmental and economic perspectives [48]. An LCA analysis suggests that the purchase of recycled aggregates resulting from C\&DW treatment is cost-effective only if the treatment plant is situated within a $30 \mathrm{~km}$ area [47]. Long distances between integrated waste management centers from smaller urban areas and rural communities will encourage illegal waste disposal facilities and increase the prevalence of natural aggregates in the construction sector. Mobile crushing plants combined with local storage facilities could be a solution to such settlements. At the end of its life, concrete can be recycled either back concrete as a recycled aggregate or into other applications such as road base [43]. 
The market for recycled aggregates should be improved in Romania taking into consideration sustainable economic growth in the long term. A study suggests that the price of recycled aggregates has to be kept at least $20 \%$ lower than natural aggregates which at present disregards the aggregates produced from waste [49]. Romania has access to cheap natural aggregates and such initiative is difficult to implement. Waste disposal costs and the difference in the price of recycled and natural aggregates could play as key factors to the success of C\&DW recycling practices among the new EU Member States [14].

Experiments conducted shows that replacing $25 \%$ of natural materials with recycled aggregates has no significant adverse effect on structural concrete performance [50].

Another LCA analysis concludes that recycled aggregates should be considered as a complementary resource and not a full alternative to the use of natural aggregates taking into account the current large demands in the Romanian construction sector [47]. At European level, the main barriers derive from commercialization of such recycled aggregates, the market of virgin materials or their logistics and not from recycling technology side, particularly for concrete and ceramic wastes [5] Guignot et al. [51] propose a new recycling scheme for C\&DW fraction using an electrical fragmentation technology. This technology reintroduced the concrete wastes in the loop to produce new concrete for buildings and supply part of the raw feed of a clinker kiln.

Besides the conservation of natural resources and reduced landfill areas, the implementation of recycled aggregates in ready-mix concrete will also encourage further research and development of sustainable construction [52]. The same approach must be promoted in Romania to accelerate the transition from a linear towards a circular economy avoiding natural resource depletion.

\subsection{Regional Approach of Sustainable CED Waste Management System (Stage III-V)}

A crucial challenge is to integrate the C\&DW management activities at the county level, including urban and rural municipalities. A feasibility study regarding the implementation of an integrated C\&DW management system in Hunedoara County suggests the following proposals [53]:

- Nine special storage areas for C\&DW located in urban areas (Brad, Petrosani, Calan, Orastie, Petrila, Lupeni, Uricani, Aninoasa)

- central storage near the municipal integrated waste management system located in Bircea Mare where a mobile crushing facility $(20 \mathrm{t} / \mathrm{h})$ is operational with the mention that this facility could be transported to above urban storage areas if requested

- Special storage sites for rural localities with recommended areas about $20 \mathrm{~m} \times 20 \mathrm{~m}$, which must be enclosed

- Several special containers (capacity-7 $\mathrm{m}^{3}$ ) in urban areas and one in each commune

- One container $(1.1 \mathrm{mc})$ located in each village beside municipal waste bins

$C \& D W$ generated from rural areas are transported to the nearest urban storage area listed above. The same study stipulates that the inert materials will be recovered on road construction, sorted fractions (metals, glass, plastic, wood) will be sent to recycling companies, and C\&DW refusals will be used in fillings or as inert material cover for sanitary landfill of Bârcea Mare [53]. The use of different types of C\&DW materials (recycled concrete aggregates, crushed bricks, reclaimed asphalt pavement) in the base and subbase layers of roadways has been proven to be an excellent alternative to natural aggregates without a great loss of infrastructure performance [54].

A key issue is to be able to make the transition from civil construction stage (backfilling, road base, cover material, foundations) to reuse of such materials into buildings via qualitative recycled aggregates at affordable prices. 
A holistic approach to $C \& D$ waste management activities is imperative for regional and local decision-makers. Yeheysis et al. [4] propose a construction waste LCA-based integrated sustainability index considering environmental, economic and social indicators.

Waste management activity is a complex activity, which involves technical, environmental, economic, social, governance and policy dimensions at various geographical scales (local, regional, national, EU).

First of all, law must establish proper monitoring of C\&DW flows in order to have a reliable database (involving waste operators and construction companies). Building permits must include the obligation for individuals or companies to report the amounts of C\&DW generated and to stipulate how this waste stream should be properly managed. These actions must be supported by proper law enforcement of environmental and local authorities. The future increase of landfill fees will discourage the dispose of such fraction in urban or regional landfills and will encourage stakeholders to pay more attention to recycling and recovery activities.

Current waste management practices rely on the local recovery of this fraction (backfilling, roads, foundations) or disposal in urban landfills or scattered across public or private lands as wild dumps. The implementation of regional integrated municipal waste management systems should mitigate the issues raised by improper activities related to C\&DW fraction. These major projects are financed by through European funds (2007-2013; 2014-2020) and supervised by county councils. However, the implementations of such projects are regularly behind the schedule due to bureaucracy, tender appeals, political challenges, governance issues, and court cases. Such delays, combined with the closure of non-compliant landfills, lead to illegal dumping practices or temporary dumpsites due to the lack of alternative sanitary disposal sites [38]. Also, recycling, treatment facilities, waste collection and transportation schemes are affected, including those attributed to C\&DW flows. Illegal disposal of $C \& D W$ is still a widespread practice due to the lack of coherent legislation, poor enforcement of local authorities in this regard, insufficient storage and treatment facilities. The current crushing plants, which frequently serve mainly one urban area, should expand their coverage towards surrounding rural municipalities. On-site recovery and recycling practices using a mobile crushing facility could be an optimal solution for construction companies. Mobile treatment facilities seem to be the best option for solving the C\&D waste management issues in Croatia [14]. Case studies from Ireland reveal the need for co-operative collaborative contractual arrangements to facilitate early involvement of project stakeholders and setting waste performance targets for the main constructor and subcontractors [55]. In Australia, the strategies for improving reuse of construction waste include sector-wide education and training in the field, better communication between actors which deals with waste materials reuse; more effective legislative and financial incentives; better on and off-site waste management facilities and Extended Producer Responsibility [56].

These are general strategies with worldwide coverage concerning on-site recovery improvement. Effective implementation of construction waste sorting requires a wide range of factors involving human beings, management, technology, environment and resources [57]. Furthermore, a reliable estimation of costs associated with waste flows will help decision-makers to enhance the appropriate strategy that can mitigate the C\&DW generation [58].

The backfilling, landfill covers, the base for roads and buildings are the main waste diversion routes from wild dumps and municipal landfill sites. In rural areas, local recovery practices are observed (buildings foundations, filling material, unpaved roads), but without basic C\&DW waste management facilities. Mobile crushing facilities could be a reliable option for smaller urban areas and surrounding rural communities. 


\section{Conclusions}

The paper points out the challenges of C\&D waste management activities in Romania in the context of poor waste management facilities dedicated to this waste fraction. The paper identifies five stages of $C \& D W$ on the sustainable route starting with a worst-case scenario (stage I) such as illegal dumping on surroundings (which still prevails across rural communities) towards building materials using recycled items (e.g., recycled aggregates) under a circular economy approach (stage V). The paper highlights the geographical dimension of C\&DW flows across Romanian counties and huge amounts of C\&DW, which are not covered by waste statistics as shown by the thematic maps.

Several routes for sustainability in C\&DW management in Romania are outlined via the following options: development of crushing plants in each urban area, mobile crushing plants for construction companies (on site recovery) or destined for small cities and rural communities; special storage areas and containers for C\&DW collection and disposal activities, the expansion of co-waste processing activities in Romanian cement industry, the development of recycled aggregates sector supported by a reliable economic market. These activities are necessary to develop a circular economy system of C\&DW flows, focusing on interactions between III, IV, and V stages. These stages should be examined for other transition and developing countries across the globe, which are facing similar conditions in terms of poor infrastructure for $C \& D W$ management. The paper reveals some promising practices in urban areas (pilot projects) and analyzes the future prospects in supporting the reuse, recovery, and recycling activities of $C \& D W$ as building materials in a circular economy approach. To achieve such a transition, urban and rural municipalities must be part of an integrated C\&DW management system.

Funding: This work was supported by a grant of the Alexandru Ioan Cuza University of Iasi, within the Research Grants program, Grant UAIC, code GI-UAIC-2017-06.

Conflicts of Interest: The author declares no conflict of interest. The funders had no role in the design of the study; in the collection, analyses, or interpretation of data; in the writing of the manuscript, or in the decision to publish the results.

\section{References}

1. Umar, U.A.; Shafiq, N.; Malakahmad, A.; Nuruddin, M.F.; Khamidi, M.F. A review of the adoption of novel techniques in construction waste management and policy. J. Mater. Cycles Waste Manag. 2017, 19, 1361-1373. [CrossRef]

2. Ghosh, S.K.; Ghosh, S.K. Construction and Demolition Waste in Sustainable Solid. Waste Manag. 2016, 16, 511-547. [CrossRef]

3. Joint Research Center (JRC) of European Commission. Supporting Environmentally Sound Decisions for Construction and Demolition (CED) Waste Management; A practical guide to Life Cycle Thinking (LCT) and Life Cycle Assessment (LCA); JRC: Belgium, Brussels, 2011.

4. Yeheyis, M.; Hewage, K.; Alam, M.S.; Eskicioglu, C.; Sadiq, R. An overview of construction and demolition waste management in Canada: A lifecycle analysis approach to sustainability. Clean Technol. Environ. Policy 2013, 15, 81-91. [CrossRef]

5. Gálvez-Martos, J.-L.; Styles, D.; Schoenberger, H.; Zeschmar-Lahl, B. Construction and demolition waste best management practice in Europe. Resour. Conserv. Recycl. 2018, 136, 166-178. [CrossRef]

6. Adams, K.; Osmani, M.; Thorpe, T.; Thornback, J. Circular economy in construction: Current awareness, challenges, and enablers. Proc. Inst. Civ. Eng. Waste Resour. Manag. 2017, 170, 15-24. [CrossRef]

7. Nussholz, J.L.K.; Rasmussen, F.N.; Milios, L. Circular building materials: Carbon saving potential and the role of business model innovation and public policy. Resour. Conserv. Recycl. 2019, 141, 308-316. [CrossRef]

8. Dent, B.D. Cartography: Thematic Map Design; McGraw-Hill: Boston, MA, USA, 1999.

9. Law no 211 on the Waste Regime. 2011. Available online: https:/www.ecotic.ro/wp-content/uploads/2017/ 04/legea-211-2011-forma-sintetica-pentru-data-2017-04-19.pdf (accessed on 9 January 2019).

10. Musuroaea, V.; Agapie, C.; Toniuc, M.; Ghita, C. Analysis of National Situation with Regard to the Generation, Collection, Treatment, and Valorification of C\&D Waste (CDW). 2012. LIFE ENV/RO/00727. Available online: http://life-dcd.ro/documente/?did=2 (accessed on 6 November 2018). (In Romanian) 
11. National Waste Management Plan (version 5). Available online: http://mmediu.ro/app/webroot/uploads/ files/PNGD_vers5.pdf (accessed on 14 January 2018). (In Romanian)

12. EC. Construction and Demolition Waste Management 2015. Available online: http://ec.europa.eu/ environment/waste/studies/deliverables/CDW_Romania_Factsheet_Final.pdf (accessed on 10 January 2018). (In Romanian)

13. Macias, A.; WPiniarsk. Municipal Solid Waste Management Problems on a Local Scale: A Case Study from Rural Poland. Pol. J. Environ. Stud. 2016, 25, 1623-1632. [CrossRef]

14. Bedeković, G.; Zelić, B.K.; Sobota, I. Construction and demolition waste management in Croatia with recycling overview. Detritus 2018, 4, 122-128. [CrossRef]

15. EPA Harghita. An Environmental Status Report in Harghita County in 2015; EPA: Washington, DC, USA, 2016.

16. Gurau, M.A.; Melnic, L.V.; Armeanu, E. Waste management strategy in construction and demolition industries: Constanta district. Theor. Empir. Res. Urban Manag. 2011, 6, 84-92.

17. Tam, V.W.-Y.; Lu, W. Construction waste management profiles, practices, and performance: A cross-jurisdictional analysis in four countries. Sustainability 2016, 8, 190. [CrossRef]

18. Simion, I.M.; Ghinea, C.; Maxineasa, S.G.; Taranu, N.; Bonoli, A.; Gavrilescu, M. Ecological footprint applied in the assessment of construction and demolition waste integrated management. Environ. Eng. Manag. J. 2013, 12, 779-788.

19. Saca, N.; Dimache, A.; Radu, L.R.; Iancu, I. Leaching behavior of some demolition wastes. J. Mater. Cycles Waste Manag. 2017, 19, 623-630. [CrossRef]

20. Drăgan, G.; Marinoiu, A.M.; Voicu-Dorobanţu, R. Construction and Demolition Waste Management: A Case Study on Romania. In Proceedings of the 3rd WSEAS International Conference on Waste Management, Water Pollution, Air Pollution, Indoor Climate (WWAI'9), Tenerife, Spain, 1-3 July 2009; pp. 482-485.

21. Huang, $\mathrm{X} . ; \mathrm{Xu}, \mathrm{X}$. Legal regulation perspective of eco-efficiency construction waste reduction and utilization. Urban Dev. Stud. 2011, 9, 90-94.

22. EPA Iasi. An Environmental Status Report in Iasi County in 2014; EPA: Washington, DC, USA, 2015.

23. EPA Salaj. An Environmental Status Report in Salaj County in 2015; EPA: Washington, DC, USA, 2016.

24. EPA Dambovita. An Environmental Status Report in Dambovita County in 2014; EPA: Washington, DC, USA, 2015.

25. Directive 2008/98/EC of the European Parliament and of the Council of 19 November 2008 on Waste and Repealing Certain Directives (Waste Framework Directive). Available online: https:/eur-lex.europa.eu/legalcontent/EN/TXT/?uri=CELEX:32008L0098 (accessed on 9 January 2019).

26. EPA Neamt. Integrated Environmental Authorization for Sanitary Landfill and Related Waste Management Facilities. Beneficiary: Piatra Neamt Hall; EPA: Washington, DC, USA, 2017. Available online: https: //www.primariapn.ro/documents/10179/2638035/autorizatie_mediu_2017.pdf (accessed on 11 March 2019).

27. EPA Neamt. An Environmental Status Report in Neamt County in 2015; EPA: Washington, DC, USA, 2016.

28. Berg, A.B.; Radziemska, M.; Adamcová, D.; Zloch, J.; Vaverková, M.D. Assessment Strategies for Municipal Selective Waste Collection-Regional Waste Management. J. Ecol. Eng. 2018, 19, 33-41. [CrossRef]

29. Mihai, F.C.; Grozavu, A. Spatial assessment of construction waste generated by residential buildings in rural areas. In Proceedings of the 17th International Multidisciplinary Scientific Geo Conference on Informatics, Geoinformatics and Remote Sensing, Albena, Bulgaria, 2-7 July 2017; Volume 17, pp. 649-656. [CrossRef]

30. HQ Air Force Center for Environmental Excellence. Construction and Demolition Waste Management Pocket Guide; Prepared by 3D/International; HQ Air Force Center for Environmental Excellence: Brooks, Texas, USA, 2006.

31. Kofoworola, O.F.; Gheewala, S.H. Estimation of Construction Waste Generation and Management in Thailand. Waste Manag. 2009, 29, 731-738. [CrossRef] [PubMed]

32. Ram, V.; Kalidindi, S.N. Estimation of construction and demolition waste using waste generation rates in Chennai, India. Waste Manag. Res. 2017, 35, 610-617. [CrossRef] [PubMed]

33. Villoria Sáez, P.; del Río Merino, M.; Porras-Amores, C. Estimation of construction and demolition waste volume generation in new residential buildings in Spain. Waste Manag. Res. 2012, 30, 137-146. [CrossRef]

34. Miatto, A.; Schandl, H.; Forlin, L.; Ronzani, F.; Borind, P.; Giordano, A.; Tanikawa, H. A spatial analysis of material stock accumulation and demolition waste potential of buildings: A case study of Padua. Resour. Conserv. Recycl. 2019, 142, 245-256. [CrossRef] 
35. INS. Tempo-Online Database. Available online: http://statistici.insse.ro:8077/tempo-online/\#/pages/tables/ insse-table (accessed on 9 January 2019).

36. EPA Neamt. An Environmental Status Report in Neamt County in 2017; EPA: Washington, DC, USA, 2018.

37. Zainun, N.Y.; Rahman, I.A.; Rothman, R.A. Mapping of construction waste illegal dumping using geographical information system (gis). In Proceedings of the IOP Conference Series: Materials Science and Engineering, Kazan, Russia, 20-25 October 2016; p. 012049. [CrossRef]

38. Mihai, F.C. Waste collection in rural communities: Challenges under EU regulations. A case study of Neamt County, Romania. J. Mater. Cycles Waste Manag. 2018, 20, 1337-1347. [CrossRef]

39. Leopold, D.; Goga, M.; Meissner, R. Develop a Good Practice Guide on Construction and Demolition Waste. 2011. Available online: http://www.gestiunedeseuri.ro/activitati-proiect/activitatea-6.2.-elaborarea-unuighid-de-bune-practici-privind-deeurile-din-construcii-i-demolri-35.html (accessed on 10 January 2018). (In Romanian)

40. Eco-Sal, S.A. Activity Report of SC Eco-Sal S.A. in 2016. Available online: http://eco-sal.ro/rapoarte-anuale/ (accessed on 10 January 2019).

41. Pereira, L.; Jalali, S.; Aguiar, J.L.B. Construction and Demolition Waste Management. Available online: http://www.domeniiprestserv.ro/despre-noi.html (accessed on 1 January 2019).

42. Bihor, E. The Concrete Crushing Plant. Available online: https://ecobihor.ro/beton_en.htm (accessed on 12 January 2019).

43. Rohan, M. Cement and concrete industry integral part of the circular economy. Rom. J. Mater. 2016, 46, 253-258.

44. Holcim. Sustainable Development Report. Available online: https://www.holcim.ro/en/sustainabledevelopment/sustainable-development-report (accessed on 11 January 2019).

45. Badea, C.; Bob, C.; Iures, L. Waste Materials Used for Building Construction. Advances in Energy Planning, Environmental Education and Renewable Energy Sources. In Proceedings of the 4th WSEAS International Conference on Energy Planning, Energy Saving, Environmental Education and Renewable Energy Sources (EPESE'10), Sousse, Tunisia, 3-6 May 2010; pp. 54-59.

46. Muscalu, M.T.; Andrei, R. Use of recycled aggregates in rigid pavement construction. Buletinul Institutului Politehnic din Iaşi Section: Constructii. Arhitectura 2011, 57, 69-79.

47. Musuroaea, V.; Agapie, C.; Toniuc, M.; Ghita, C. Report of LCA Regarding Natural and Recycled Aggregates. Available online: http://life-dcd.ro/ (accessed on 6 November 2018).

48. Simion, I.M.; Fortuna, M.E.; Bonoli, A.; Gavrilescu, M. Comparing environmental impacts of natural inert and recycled construction and demolition waste processing using LCA. J. Environ. Eng. Landsc. Manag. 2013, 21, 273-287. [CrossRef]

49. Bressi, G.; Volpe, G.; Pavesi, E. Production of Recycled Aggregates from Inert Waste. Available online: http://www.sarmaproject.eu (accessed on 12 January 2019). (In Romanian)

50. Wagih, M.; El-Karmoty, H.Z.; Ebid, M.; Okba, S.H. Recycled construction and demolition concrete waste as aggregate for structural concrete. HBRC J. 2013, 9, 193-200. [CrossRef]

51. Guignot, S.; Touze, S.; Von der Weid, F.; Menard, Y.; Villeneuve, J. Recycling Construction and Demolition Wastes as Building Materials A Life Cycle Assessment. J. Ind. Ecol. 2015, 19, 931-1102. [CrossRef]

52. Alam, M.S.; Slater, E.; Billah, A.H.M. Green Concrete Made with RCA and FRP Scrap Aggregate: Fresh and Hardened Properties. J. Mater. Civ. Eng. 2013, 25, 1783-1794. [CrossRef]

53. Tatomir, M.; Aurora, J.I.E.; Truta, C.; Stanescu, I.; Doru, I. Elaboration of Technical and Economic Documentation for Implementation in Hunedoara County of Integrated Waste Management from Construction and Demolition Activities Generated by the County'S Population. 2015, Feasibility Study. SC TOP EURO PROJECT SRL Bucharest December 2015 Beneficiary: Inter-Community Development Association "Integrated Waste Management System in Hunedoara county". Available online: http://www. cjhunedoara.ro/documente/hotarari/2016/HOTARARI\%202016/HCJH\%20065\%20-\%20ANEXA.pdf (accessed on 11 January 2019). (In Romanian)

54. Vieira, C.S.; Pereira, P.M. Use of recycled construction and demolition materials in geotechnical applications: A review. Resour. Conserv. Recycl. 2015, 103, 192-204. [CrossRef]

55. Kelly, M.; Dowd, D. A review of construction waste management practices on selected case studies in Ireland. Proc. Inst. Civ. Eng. Waste Resour. Manag. 2017, 170, 78-84. [CrossRef] 
56. Park, J.; Tucker, R. Overcoming barriers to the reuse of construction waste material in Australia: A review of the literature. Int. J. Constr. Manag. 2017, 17, 228-237. [CrossRef]

57. Wang, J.; Yuan, H.; Kang, X.; Lu, W. Critical success factors for on-site sorting of construction waste: A China study. Resour. Conserv. Recycl. 2010, 54, 931-936. [CrossRef]

58. Fadiya, O.O.; Georgakis, P.; Chinyio, E. Quantitative Analysis of the Sources of Construction Waste. J. Constr. Eng. 2014. [CrossRef]

(C) 2019 by the author. Licensee MDPI, Basel, Switzerland. This article is an open access article distributed under the terms and conditions of the Creative Commons Attribution (CC BY) license (http://creativecommons.org/licenses/by/4.0/). 